\title{
Partington syndrome
}

INSERM

\section{Source}

INSERM. (1999). Orphanet: an online rare disease and orphan drug data base. Partington syndrome. ORPHA:94083

Partington syndrome is a form of syndromic X-linked mental retardation (S-XLMR) characterised by the association of mild to moderate intellectual deficit, dysarthria and dystonic hand movements. So far, less than 20 cases have been described in the literature. The syndrome is caused by mutations in the Aristaless-related homeobox (ARX) gene (Xp22.13). Transmission is X-linked recessive. 